\section{Jörgen Vijgen}

Thomas Instituut te Utrecht (Netherlands) jorgen.vijgen@skynet.be

DOI: http://dx.doi.org/10.12775/BPTh.2016.030

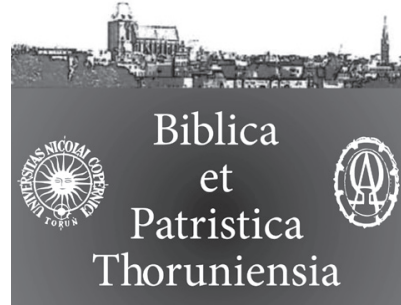

9 (2016) 3: 213-219

ISSN (print) 1689-5150

ISSN (online) 2450-7059

\title{
The Future of Biblical Thomism: Reflections on the French translation of Thomas Aquinas's commentaries on Paul's Letters to the Philippians and the Colossians
}

\author{
Przyszłość tomizmu biblijnego: \\ refleksje nad francuskim przekładem komentarzy \\ św. Tomasza z Akwinu \\ do Listów św. Pawła do Filipian i Kolosan
}

$\mathbf{R}_{\text {ecent years have seen the appearance of a new 'version'1 of Thomism, so- }}$ of Thomism by putting an adjective before the noun results in creating the impression that in fact there exist different types of Thomism, the term 'Biblical Thomism' does not have this relativistic connation. 'Biblical Thomism', rather, refers to the growing appreciation of Thomas Aquinas as a biblical scholar and to a renewed interest in his Bible commentaries. This reading of Thomas Aquinas attempts to broaden the well-known picture of Aquinas as a systematical theologian and commentator of Aristotle by exploring Aquinas's biblical commentaries and looking at his thought through the lens of his biblical exegesis and use of the Church Fathers. In doing so it is argued that Aquinas's exegetical project, combining various exegetical practices with speculative reasoning, has much to teach contemporary theology and biblical studies. Moreover, Thomas himself would have found the division between biblical exegesis and theology an artificial division because precisely as a Magister in Sacra Pagina he taught theology by lecturing on a book of the Bible, employing all the exegetical, histo-

1 I am referring to the book by F. Kerr, After Aquinas: Versions of Thomism. 
rical, philosophical and theological tools at his disposal. In short, for Aquinas doing theology is "a form of speculative reading of the revealed Word of God."

The credit for underlining the importance of Thomas Aquinas the exegete goes to the Dominican Father Ceslaus Spicq with his work Esquisse d'une histoire de l'exégèse latine au Moyen Age, published in 1944 and to his lengthy and still most valuable but sometimes forgotten contribution of 1946, entitled 'Saint Thomas d'Aquin Exégète' in the Dictionnaire de Théologie Catholique ${ }^{3}$. At that time there were no critical editions of his Bible commentaries available. In the 1960's and 1970's the Leonine Commission, charged with the critical edition of Aquinas's works by Pope Leo XIII, published his commentaries on the Book of Job and on Isaias, advancing considerable our knowledge of Aquinas's exegetical practices and those of his predecessors and contemporaries.

The future of Biblical Thomism has indeed, as its necessary conditions, both an advanced knowledge of the exegetical practices of his immediate predecessors and contemporaries as well as the availability of a critical edition of his Bible commentaries. Regarding the former, considerable progress has been made since the time of Father Spicq and others. It suffices to mention for instance recent work on Hughes of St. Victor ${ }^{4}$, Etienne Langton ${ }^{5}$, monastic exegesis $^{6}$, William of Alton ${ }^{7}$ and others. ${ }^{8}$ In particular the French historian Gilbert Dahan has over the course of many years devoted numerous studies to various

2 See the introduction I wrote, together with Piotr Roszak, Towards a 'Biblical Thomism': Introduction, in: P. Roszak and J. Vijgen (eds.), Reading Sacred Scripture with Thomas Aquinas, vii-xvi (Textes et Études du Moyen Âge 80). The book is a result of an international conference, entitled 'The biblical exegesis of Thomas Aquinas and its contemporary relevance', held at the Nicolaus Copernicus University in April 2015. Some of the papers were published in the special issue of Biblica et PatristicaThoruniensia 8 (3/2015): Biblical Thomism I

3 Edited by A. Vacant, E. Mangenot, E. Amann, Libraire Letouzey et Ané, col. 694-738. One should also mention Pope Pius XII' speech on January 14, 1958, in which he praises the Bible commentaries of Aquinas as "his most important theological works". See AAS 50 (1958), 151-152.

4 Hugues de Saint-Cher $(\dagger 1263)$, bibliste et théologien, ed. by G. Dahan, L.-J. Bataillon and P.-M. Gy, Brepols, Turnhout, 2004.

5 Étienne Langton, prédicateur, bibliste, théologien, ed. by. G. Dahan, N. Bériou and R. Quinto, Brepols, Turnhout, 2010.

6 Lexégèse monastique au moyen âge (xie-xive s.), ed. by G. Dahan and A. NoblesseRocher, Paris, Institut d'Études augustiniennes, 2014.

7 T. Bellamah, The Biblical Interpretation of William of Alton.

8 An excellent first introduction is F. Van Lierde, An Introduction to the Medieval Bible. 
authors and topics in the field of medieval exegesis, establishing himself the authority par excellence in this field of research. ${ }^{9}$

Regarding the latter, the availability of a critical edition of Thomas's Bible commentaries, the current situation is quite different. Apart from the editions of the commentaries on Job and Isaiah, published in the 1960's and 1970's, no critical editions are available at the moment and it is unlikely that critical editions of his other commentaries (Jeremiah, Psalms, John, Matthew, Corpus Paulinum) will appear in the near future, with the exception of his commentary on Romans, prepared by Father Gilles de Granpré O.P.

Due to these circumstances but also despite them and taking into account the decreasing reading knowledge of Latin among scholars and students, there have been many translations of his Bible commentaries into the vernacular. Since 1996 Jean-Éric de Stroobant de Saint-Éloy O.S.B. has taken upon himself the monumental task of translating Aquinas's Bible commentaries into French. So far his translations of the Commentary on the Psalms (1996), the Commentary on Romans (1999), First Corinthians (2002), Second Corinthians (2005), Galatians (2008) and Ephesians (2012) have appeared. ${ }^{10}$ One can now add to this impressive list his translation of the Commentaries on Philippians and Colossians. ${ }^{11}$ According to Aquinas, the principal topic of these Letters are the consolidation and progress of ecclesiastical unity (Philippians) and its defense against errors (Colossians). ${ }^{12}$

What distinguishes this translation from other translations is first of all the number of indices it provides. Each translation concludes with an index of scriptural references, an index of topics treated, an index of loci parallelli and an index of the cited authors and works. These indices are most welcome tools for

9 See his L'exégèse chrétienne de la Bible en Occident médiéval, XIIe-XIVe siècles. For a full list of his publications see http://lem.vjf.cnrs.fr/spip.php?article88\&lang=fr

10 These translations are published by Les Éditions du Cerf, Paris. Regarding the translation of the Commentary on the Psalms, one should take into account the critical remarks by M. Morard who is preparing the critical edition. See M. Morard, $\grave{A}$ propos $d u$ Commentaire des Psaumes de saint Thomas d'Aquin, Revue Thomiste 96 (1996), pp. 653-670.

11 The complete bibliographical reference: Thomas d'Aquin, Commentaire de l'Épître aux Philippiens suivi de Commentaire de l'Épitre aux Colossiens. Introductions par Gilbert Dahan et Walter Senner O.P.. Traduction et tables par Jean-Éric de Stroobant de Saint-Éloy O.S.B.. Annotation par Jean Borella et Jean-Éric de Stroobant de Saint-Éloy O.S.B., Les Éditions du Cerf, Paris 2015, 433 p.

12 See the introduction to his commentary on Romans: "Agit ergo apostolus, primo quidem, de institutione ecclesiasticae unitatis in epistola ad Ephesios; secundo, de eius confirmatione et profectu in epistola ad Philippenses; tertio, de eius defensione, contra errores quidem, in epistola ad Colossenses". 
investigating the use of a Bible verse or author by Aquinas. More importantly, the translations are each time prefaced by lengthy and scholarly introductions, containing moreover a summary list of the known commentaries on the work that is being presented up until the $13^{\text {th }}$ century, many of them never printed or edited, as well as well as a detailed lay-out of the structure of the commentary, something which is needed for the contemporary reader who is not familiar with the method of 'divisio textus'. With regard to the Letter to the Philippians, thirty-three commentaries are listed; regarding the Letter to the Colossians, thirty-two commentaries are listed.

Another distinguishing feature are the scholarly introductions. Gilbert Dahan, who also provided the introductions for the 2002, 2005, 2008 and 2012 translations, focuses in his introduction (pp. 11-37) on Thomas's exegetical method as well as the historical context of his commentary. Dahan rightly underlines the principal difference with regard to contemporary exegesis, namely the confessional nature of the exegetical practice but he also emphasizes that, by considering Scripture as the Word of God, this does not lessen the "objective approach" (p. 12) of Aquinas. Dahan first mentions the insertion of quaestiones into the commentary. A telling example is Phil. 1:9 ("it is my prayer that your love may abound more and more, with knowledge and all discernment") which occasions Aquinas to pose the question whether knowledge (scientia) proceeds from love. Next, Dahan studies the use of the Glossa, the standard commentary on Scripture in the $12^{\text {th }}$ century as well as the method of 'divisiotextus'. Another procedure Dahan mentions is the use of Scripture itself. The numerous quotes from Scripture are not a mere illustration but serve to justify or deepen the understanding of the text.Dahan places Aquinas's commentary within an historical perspective by studying his prologue and offering three examples of verses (Phil. 1: $1 ; 1: 23 ; 2: 5-11 ; 3: 2$ ) as read by medieval exegetes, often relying on his remarkable knowledge of unedited manuscripts.

Another remarkable feature of the translation is its use of manuscripts. The following manuscripts are consulted: Florence (MediceaLaurenziana, S. Croce, Pl. 28, d. 11), Munich (Clm 21209), Oxford (New College Library 63, ff. I. 234), Turin (Torino, BibliotecaNazionale, lat. E. II. 13) and Venice (Venezia, Biblioteca Nazionale Marciana Lat. I. 54). This results in numerous corrections to the standard Marietti text, corrections carefully noted in the footnotes to the translation. As a result this French translation offers, paradoxically, the best text of Aquinas's commentary available to scholars.

Opening the commentary itself, one immediately notices the question Aquinas devotes to Phil. 1, 1 ("To all the saints in Christ Jesus who are at Philippi, with the bishops and deacons"). Why aren't the priests mentioned, 
Aquinas asks. The use of the plural (episcopi), however, indicates that the priests are intended as well. Here we come across another distinguishing feature. The extensive footnote on p. 65 discusses this verse in several Church Fathers but also mentions the positions of contemporary exegetes. Another example occurs in footnote 3 on pp. 70-71 where the translator gives an extensive explanation of the term 'habitus', employed by Thomas Aquinas in his commentary. Paul's admonition in Phil. 2:3 ("in humility count others better than yourselves") occasions Thomas to pose the following question: "But how can a superior person do this? For he either does not know that he is superior and virtuous, and then he is not virtuous, because he is not prudent; or he does know, and then he cannot consider some as superior to himself." The translator rightly notes on pp. 89-90 that the claim that the ignorance of one's superiority would implicate the absence of prudence needs a proper understanding of the notion of prudence. In an extensive footnote he offers a brief history of phronesis or prudential reasoning and contrasts it with its modern meaning. Another interesting passage occurs in Phil. 2:6 ("though he was in the form of God") where Aquinas asks why Paul says "in the form" rather than "in the nature". Again, this occasions the translation to devote an extensive footnote to the differences between these terms in the works of Aquinas (pp. 95-96). Another example might be Thomas's exegesis of the term 'book of life' (Phil. 4:3) and the corresponding footnote on pp. 141-142, offering a small treatise on predestination in Aquinas. Many other examples could be given but the 15 page-bibliography (pp. 155-170) of the works quoted in the footnotes of the translation indicate already the meticulous care with which Father Stroobant de Saint-Éloy a pproached his richly annotated translation.

The annotated translation of his commentary on Colossians reaches the same high standards. The translation is prefaced by an introduction, written by Walter Senner O.P. (pp. 207-253). He starts with general remarks on the kind of Bible text Aquinas used, the four senses of Scripture and the history of scholastic exegesis. He devotes some observations to what he calls the "salient" passages in the commentary. There is for instance Aquinas's use of the phrase "omnis cognitio terminatur ad existens, id est ad aliquam naturam participantem esse" in Colos. 1:15 used to explain the term "first-born". Senner traces this phrase back to the influence of Albert the Great. Senner also brings a most interesting historical perspective on the interpretation of Col. 2: 8 ("See to it that no one makes a prey of you by philosophy and empty deceit, according to human tradition, according to the elemental spirits of the universe, and not according to Christ.") The Letter to the Colossians contains the influential description of Christ as the Head of the Body, the Church (Col. 1:18). This occasions Senner to devote a large number of pages (pp. 239-253) to the ecclesi- 
ology of Aquinas and its interpretation by Congar, the often forgotten Charles Journet, George Sabra and Ot-Hermann Pesch.

The principal theme of the Letter to the Colossians, according to Aquinas, is the defense of the Church against errors and in particular against the error of Arians. In this regard the many historical and doctrinal footnotes are extremely useful to the reader, especially in Col. 1: 15-20. On many occasions, the translator also includes historical surveys of difficult terms or phrases such as 'fomes' (p. 350), or "novus creatus, quia anima rationalis non est ex traduce, sed a Deocreata" with respect to Col. 3:10 or on terms that are read by contemporary readers with a certain uneasiness ('ira Dei'), etc. One of these difficult phrases is 4:6: "Let your speech always be gracious, seasoned with salt, so that you may know how you ought to answer every one." According to Aquinas, 'seasoned with salt' refers to "considerateness or discretion, because just as salt makes food savory, so every inconsiderate action is bitter and irregular." (p. 375). The commentary also contains interesting (and perhaps controversial) remarks on the relation between the Church and Old Testament prescriptions. When Paul advises not to pass judgment in questions of food, drink or the Sabbath, saying these "are only a shadow of what is to come; but the substance belongs to Christ" (Col. 2:17) ${ }^{13}$ Aquinas comments: "When someone sees a shadow, he expects the body to follow. Now the legal observances of the law were the shadow going before Christ, and they signified his coming; and so Paul says, the body, that is, the truth of the thing, belongs to Christ, but the shadow belongs to the law." (p. 341). Somewhat further, with regard to Col. 2:19 ("and not holding fast to the Head, from whom the whole body, nourished and knit together through its joints and ligaments, grows with a growth that is from God.) we find an exemplary articulation of what it means that Christ is the Head. Answering that the entire good of the body, which is the Church, depends on Christ, Aquinas continues by saying that in a natural body the members are joined in a twofold way. One way is by contact, as the hand is joined to the wrist, and the other way is by a connection, as being joined by nerves. The "joints and ligaments" of which Paul writes refer to the faith and understanding by which the members are joined in the Church. But Aquinas adds that this would be "incomplete without the ligaments of charity and the sacraments. Thus Paul says, nourished through ligaments, because it is through charity that one person supplies another." (nr. 129, p. 343). Again, the bibliography for the commentary (pp. 379-394) gives a good indication of the wealth of material used in the notes.

13 Aquinas reads: "quæsunt umbra futurorum: corpus autem Christi" but understands the phrase correctly when he notes that 'corpus' refers to the truth of the thing, which belong to Christ (nr 121, p. 341). 
The scholarly community owes an enormous debt of gratitude to the meticulous work of Jean-Éric Stroobant de Saint-Éloy and his collaborators, not only for offering this translation but also, and perhaps more important for scholars outside France, for offering a linguistic, historical and doctrinal guide to reading this commentary.

\section{References}

Bellamah, T., The Biblical Interpretation of William of Alton, Oxford University Press, Oxford 2011.

Dahan, G., Lexégèse chrétienne de la Bible en Occident médiéval, XIIe-XIVe siècles, Éditions du Cerf, Paris 1999.

Kerr, F., After Aquinas: Versions of Thomism, Blackwell, Malden 2002.

Morard, M., À propos du Commentaire des Psaumes de saint Thomas d'Aquin, Revue Thomiste 96 (1996), pp. 653-670.

Roszak, P., Towards a 'Biblical Thomism': Introduction, in: P. Roszak and J. Vijgen (eds.), Reading Sacred Scripture with Thomas Aquinas. Hermeneutical Tools, Theological Questions and New Perspectives, Brepols, Turnhout 2015, vii-xvi (Textes et Études du Moyen Âge 80).

Vacant, A., Mangenot, E., Amann, E. (eds.), Dictionnaire de Théologie Catholique, Libraire Letouzey et Ané, Paris 1946, col. 694-738.

Van Lierde, F., An Introduction to the Medieval Bible, Cambridge University Press, New York 2014. 